\title{
THE MICRONUTRIENT STATUS OF SOME SOIL SUPPORTING OIL PALM PLANTATIONIN NIFOR, BENIN CITY, BENIN
}

\author{
Ogeh, J.S., ${ }^{1}$ Imogie, A.E. ${ }^{2}$ and Maduakor C.S. ${ }^{3}$ \\ ${ }^{1}$ Department of Soil Science and Land Resource Management, Faculty of Agriculture, University of Benin, Benin \\ city, Edo State, Nigeria, e-mail: joseph.ogeh@uniben.edu \\ ${ }^{2}$ Agronomist, Nigerian Institute for Oil Palm Research PO Box 1030, Edo State Nigeria, E-mail: \\ imogie@yahoo.com \\ ${ }^{3}$ Graduate Student, Department of Soil Science, Faculty of Agriculture, University of Nigeria Nsukka, Nigeria, E- \\ mail: chikasomadina71@gmail.com
}

\begin{abstract}
This study was conducted to assess the micronutrient status of soils under three different management practices at the Nigerian Institute for Oil Palm Research (NIFOR), Benin City, Edo State, Nigeria. Soil samples were collected from three different fields with different management practices. The samples were air dried and analyzed for $\mathrm{Fe}, \mathrm{Zn}, \mathrm{Cu}$, and Mn contents using standard method. Data was subjected to ANOVA and correlation studies. Result showed that soil micronutrient status was generally low as revealed by their estimated levels of availability: field 53 $(\mathrm{Mn}=0.0333 ; \mathrm{Zn}=3.723 ; \mathrm{Cu}=2.04 ; \mathrm{Fe}=6.4)$, field $56(\mathrm{Mn}=0.0367 ; \mathrm{Zn}=3.737 ; \mathrm{Cu}=1.12 ; \mathrm{Fe}$ $=7.0939)$, field 71 (Mn = 0.0167; $\mathrm{Zn}=3.860 ; \mathrm{Cu}=2.89 ; \mathrm{Fe}=7.243)$. Fe and $\mathrm{Zn}$ were above critical level for the 3 fields. Mn was below the critical level for the 3 fields and was significantly higher in field 56 (Orlu and Kulfo series) ( $p \leq 0.05$ ). There was no significant difference among the fields for $\mathrm{Zn}(\mathrm{p} \leq 0.05)$. They were all similar. Fe was significantly different in field 53 (Kulfo and Alagba series) but similar in fields 56 and 71 ( $p \leq 0.05)$. Cu was significantly different in the 3 fields tested with field 71 (Orlu and Alagba series) higher than the critical level. Correlation studies showed that $\mathrm{pH}$ had a positive and significant correlation with Fe and Zn as observed in fields 71 and 56 ( $r=0.9934, P \leq 0.05)$ and $(r=0.9997, P \leq 0.05)$ respectively. $C u$ was the only micronutrient that has correlation with clay on each of the fields: 53,56 and $71(r=0.9929, P \leq$ $0.05)(r=0.9988, P \leq 0.05)$ and $(r=0.9967, P \leq 0.05)$ respectively. Strong correlation existed between clay and Fe in field $53(r=1, P \leq 0.05)$. The concentration of the micronutrients (Fe, Mn, $\mathrm{Zn} \mathrm{Cu}$ ), in field 53 were not extreme (neither the highest nor lowest) when comparing the three fields indicating that BMP (Best Management Practice) may be the best for maintaining good micronutrient level in soils supporting oil palm. Fields 53 and 56 is adequate in Fe and Zn but not adequate in Mn and $\mathrm{Cu}$ while field $\mathrm{T1}$ was adequate in $\mathrm{Zn}, \mathrm{Fe}$, and $\mathrm{Cu}$ but not in Mn. Based on the result of this experiment, adequate fertilizers of these micronutrients as their respective sulphates or impurities should be added to maintain proper micronutrient level.

Keywords: oil palm, micronutrient deficiency, management practices, extractable nutrient, soil fertility
\end{abstract}

\section{INTRODUCTION}

Oil palm (Elaeisguineensis Jacq.), is a globally, economic tree and source of food. It is an important crop supplying local and international demands for vegetable oil, palm wine, palm kernel cake for feeding livestock, and palm oil for making soap, pomade, and margarine candles (Okolo 2019). To ensure continuous supply and production into the future, the condition of the soil with emphasis on micronutrient, in oil palm plantation must be maintained or improved. Oil palm thrives best in well drained deep loamy moist and alluvial soil rich in organic matter and plant nutrients. Therefore, adequate nutrient must be supplied to the oil palm for optimum growth, development and production. According to NIFOR (1999), the acid soils supporting oil palm cultivation in Nigeria are deficient in macro and micro nutrients. Udom (2002) also stated that there is a decline in the yield of oil palm plantation in Nigeria which he attributed to persistent decline in soil fertility.
Micronutrients are essential mineral elements for growth, but plants generally require small amount of them. These elements include Boron (B), Iron (Fe), Manganese (Mn), Zinc (Zn), and Copper (Cu). Micronutrients are not needed in large quantity but in small amount, but they play important roles in the overall yield and optimum productivity as well as the fertility of the soil. Their absence can better be explained by the term "hidden hunger" (Nutrient element deficiency with little or no symptom that leads to a significant reduction in crop yield). According to Brady(1996), micronutrients have become more of concern because crop removal of these trace nutrients have in some cases lowered their concentration in the soil below that required for normal growth.

The roles of these micronutrients are not limited to plants only but also encompass the beneficial activities of the micro-organisms and in extension human beings (Atefeh, 2010). 
BAJOPAS Volume 14 Number 1,June, 2021

It becomes increasingly important as the available micronutrients are being shared by the plants and the microbes for growth and maintenance (metabolic activities). Iron (Fe), and Molybdenum (Mo) can be oxidized by these microbes and used for metabolism. $\mathrm{Fe}, \mathrm{Mn}$, and $\mathrm{Cu}$ are important component of enzyme system in plants which helps to carry out oxidationreduction reaction. $\mathrm{Zn}$ is linked to the growth hormone auxin. It therefore means that these reactions would not be possible without these micronutrients. This can limit plant growth, development as well as reproduction (Alloway 2008).

The primary source of these nutrients in the soil is the parent material (Aghimien, 1985) and secondarily by organic matter. It is accepted that the total content of a plant nutrient in a soil is not a reliable indication of its capacity to supply that element to a plant. It is however the amount potentially available to plants rather than the content that is biologically significant. The importance of this work lies in its ability to assess the condition and relative amount of these micronutrients in the soil supporting oil palm: to determine the effect of various management practices on micronutrients status on soil supporting oil palm as well as their micronutrients levels of concentration (deficiency and toxicity).

\section{MATERIALS AND METHODS}

\section{Soil and Vegetation of NIFOR}

The experiment was conducted at the Nigeria Institute for Oil Palm Research (NIFOR), Benin City, Edo State, Nigeria during the end of rainy season 2016. NIFOR lies between latitude $6^{0} 33^{\prime}$ to $7^{0} 25^{\prime} \mathrm{N}$ and longitude $5^{0} 15^{\prime}$ to $5^{0} 37^{\prime} \mathrm{E}$. The rainfall is high with mean annual rainfall ranging from $1,500 \mathrm{~mm}$ to $3,500 \mathrm{~mm}$ with bimodal pattern alternating with very short dry season (about 3 - 4 months).

The soils at NIFOR as described by Ogunkunle (1993) are acidic sandy soils with low silt, free drainage, and low to moderate in fertility. The natural vegetation consist of dense forest of mostly perennial trees with few deciduous species including tropical hard woods and soft wood trees such as Iroko, Obeche, numerous shrubs, woody vines etc, oil palm dominants the this vegetation which also supports the growth, development and yield of other perennial crops such as coconut, mango, cashew etc.

\section{Experimental Site}

The study investigates the micronutrient status of three fields supporting oil palm, cultivation at NIFOR. The three fields used for the study were field 53 (Kulfo and Alagba series) formally known as field 13, field 56 (Orlu and Kulfo series) formally known as field 16 and field 71 (Orlu and Alagba series) formally known as field 31 . Field 53 is where oil palm best management practices [BMP] is being carried out, while field 56 is used for mixed cropping where oil palm is intercropped with crops such as cassava, maize, melon etc. field 71 is a newly established early stage of growth ( $2-5$ years of age) oil palm field which was planted with NIFOR EWS in 2015 and is used for testing Agro-best fertilizer and Glyphosate newly developed herbicide. The soils in these fields were well drained and the color varies from dark brown to reddish brown.
Soil Sample Collection and Experimental Design

Soil samples were collected using stainless auger on $24^{\text {th }}$ November, 2016. Three random surface $(0-$ $30 \mathrm{~cm}$ depth and $1 \mathrm{~m}$ away from the palm trunk) soil samples in each site sampled were collected from three fields and made into three (3) composite soil samples. The fields where the samples were collected from include, fields 53 (Kulfo and Alagba series), 56 (Orlu and Kulfo series), and 71 (Orlu and Alagba series) respectively.

The experimental design was a randomized complete block design with 4 treatments: copper, zinc, iron manganese and three replications: fields 53 (Kulfo and Alagba series), 56 (Orlu and Kulfo series), and 71 (Orlu and Alagba series). Each of the fields had a dimension of 40 acres. The assumption is that the measurement gotten from the bulked soil samples for each of the fields is taken as the average or near average general characteristics of the individual fields.

\section{Sample Processing and Analysis}

Homogenized soil samples were air dried and sieved through $2 \mathrm{~mm}$ sieve. The sieved soil samples were then packed in properly labeled envelops for further analytical procedure. Basic determinations were carried out using standard laboratory procedures (Daiswal, 2004). Bouyoucos, (1951), hydrometer method as modified by Gee and Or (2002) was used for the mechanical analysis. Samples were extracted for cationic micronutrients (Fe, $\mathrm{Cu}, \mathrm{Mn}, \mathrm{Zn}$ ) determination using $0.1 \mathrm{~N} \mathrm{HCL}$ as described by Maclean and Langille (1976). Extractable cationic micronutrients were determined using DR-2010 Atomic Absorption Spectrophotometer. Statistical analysis was carried out using Genstat and their means compared using Duncan multiple range text at $5 \%$ level of probability Spearman correlation was used to correlate the chemical parameters.

\section{RESULT AND DISCUSSION}

\section{Physical properties}

The result of the $\mathrm{pH}$ and particle size distribution of soils of the fields sampled is shown in Table 1 . The $\mathrm{pH}$ across the fields $(53,56$, and 71$)$ were slightly acidic. This is probably as a result of high rainfall in these areas leading to leaching. The $\mathrm{pH}$ of field 53 range from $5.7-5.73$ with a mean of 5.71 . Field 56 ranges from $5.6-5.8$ with a mean of 5.70 , while field 71 ranges from $5.85-5.90$ with a mean of 5.87 . This, however, falls below $6.0-6.5$ reported to be normal for tree crops (Opeke, 1978).

Sand fraction ranges from $857-861 \mathrm{gkg}^{-1}$ for field 53; $862-865 \mathrm{gkg}^{-1}$ for field 56 and $876-896 \mathrm{gkg}^{-1}$ for field 71 . The silt fraction for field 53,56 and 71 ranges $18-20 \mathrm{gkg}^{-1} ; 20-25 \mathrm{gkg}^{-1}$ and $12-31 \mathrm{gkg}^{-}$ ${ }^{1}$ respectively. The clay fraction ranges from 119 $125 \mathrm{~g} \mathrm{~kg}^{-1} ; 110-118 \mathrm{gkg}^{-1}$ and $103-104 \mathrm{gkg}^{-1}$ for fields 53.56 and 71.

The texture across the fields $(53,56$, and 71$)$ is loamy sand. The low silt/clay ratio could possibly mean good water retention and high silt to clay conversion. The high sandy nature of the fields $(53,56$, and 71$)$ indicates that micronutrient supply, availability and uptake by crops may be difficult. This is because soils that are coarse textured (sandy) are more likely to be low in micronutrients because they have low cation binding power (Mckenzie, 2001). 
BAJOPAS Volume 14 Number 1,June, 2021

TABLE 1: Physico-chemical properties of the sampled fields

$\begin{array}{lcccccc}0-30 \mathrm{~cm} \text { depth } & \mathrm{pH} & \text { sand } & \text { silt clay } & \text { silt/clay ratio } & \text { texture } \\ \text { g/kg } & & & & & & \\ \text { - } & & & & & & \\ \text { Field } 53 & 5.71 & 859 & 18.6 & 122 & 0.15 & \text { Loamy sand } \\ \begin{array}{l}\text { Field } 56 \\ \text { sand }\end{array} & 5.7 & 863 & 23 & 113 & 0.2 & \text { Loamy } \\ \begin{array}{l}\text { Field } 71 \\ \text { sand }\end{array} & 5.87 & 881 & 21.3 & 103 & 0.2 & \text { Loamy }\end{array}$

\section{Chemical properties}

There were significant differences for manganese ( $p$ $\leq 0.05$ ) for the 3 fields under comparison as shown in Table 2. Field 56 was significantly higher than field 53. This is followed by field 71. The 3 fields had a grand mean of 0.0289 with field 53 and field 56 having values greater than the mean. The concentration of $\mathrm{Mn}$ in the 3 fields, field $53=0.0333$; field $56=0.0367$; field $71=0.0167$ were below the critical level of $1.0 \mathrm{mg} / \mathrm{kg}$ as reported by Mckenzie (2001). It therefore means that these fields are deficient in Manganese. The lowest concentration of Mn was found in field 71 and this supports the fact that oil palm takes up more nutrient at early stage of growth (2 - 5years) of which field 71 is made of. Furthermore, this lowest level in field 71 could also result from the interaction of manganese with the glyphosate herbicide to form chelates (Sundaram 1997). The general low levels of Mn across the fields could mean that there is high iron content in the soils as high level of iron can reduce the availability ofMn (liming). The low level of $M n$ in field 56 is probably due to the effect of intercropping caused by the high sequestration of the intercrops used as cassava and maize have been found to remove high amount of micronutrients in the soil.

There were no significant differences among the fields tested for $\mathrm{Zn}(\mathrm{p} \leq 0.05)$. The fields have a grand mean of 3.773 with only fields 71 having value greater than the mean. The concentration of $\mathrm{Zn}$ in the 3 fields as shown in Table 2, were higher than the critical level of $1.0 \mathrm{mgkg}^{-1}$ as reported by Mckenzie (2001). It therefore means that these fields $(53,56$, and 71$)$ have an abundance of zinc which could be considered adequate and sufficient to meet the nutrient needs of the oil palm fields.

There were significant differences for $\mathrm{Cu}$ in the fields tested. ( $P \leq 0.05$ ) the fields had a grand mean of 2.02 with fields 53 and 71 having concentrations greater than the mean. Fields 53 and 56 were below the critical level of $2.5 \mathrm{mgkg}^{-1}$ while field 71 was higher than $2.5 \mathrm{mg} / \mathrm{kg}$ critical level as reported by Mckenzie (2001). This suggests deficiency in fields 53 and 56 while field 71 is adequate and poses no nutritional problem to the fields. The lowest level was found in field 56 which has oil palm intercropped with maize, melon, and cassava. The low concentration can be attributed to the high sequestration ability of maize, other crops and removal of $\mathrm{Cu}$ by harvest of fresh fruit bunch (FFB).

Fe content in field 56 was not significantly different from field 71 but was significantly different from field $53(P \leq 0.05)$. The grand mean across the fields was 6.912 with fields 56 and 71 with values greater than the mean. The field tested $(53,56$, and 71$)$ had concentration higher than the critical level of $4.5 \mathrm{mg} / \mathrm{kg}$ as reported by Mckenzie (2001). The highest value was found in field 71 . This indicates that there is sufficient Fe to meet the palm demand for it.

TABLE 2: Extractable micronutrient content $(\mathrm{mg} / \mathrm{kg})$ of soils in the respective fields of the plantation

Fields in the oil palm plantation

\begin{tabular}{|c|c|c|c|c|c|c|}
\hline \multirow{2}{*}{$0-30 \mathrm{~cm}$ depth } & Field 53 & \multicolumn{2}{|c|}{ Field 56} & \multicolumn{2}{|l|}{ Field 71} & \multirow[t]{2}{*}{$\mathrm{CV}$} \\
\hline & & & & & & \\
\hline Mn0.0333b & & $0.0367 a$ & & $0.0167 c$ & & $6.7 \%$ \\
\hline Zn $\quad 3.723 a$ & & $3.737 a$ & & $3.86 a$ & $1.4 \%$ & \\
\hline $2.04 b$ & & $1.12 \mathrm{c}$ & $2.89 a$ & $1.12 \%$ & & \\
\hline $\mathrm{Fe}$ & $6.4 b$ & $7.093 a$ & $7.243 a$ & $3.2 \%$ & & \\
\hline
\end{tabular}

Means with similar letter(s) are not significantly different at 5\% level of probability using DMRT NS, Not significant

DMRT, Duncan Multiple Range Test

The concentration of the micronutrients ( $\mathrm{Fe}, \mathrm{Mn}, \mathrm{Zn}$ $\mathrm{Cu}$ ), in field 53 were not extreme (neither the highest nor lowest) when comparing the three fields indicating that BMP (Best Management Practice) may be the best for maintaining good micronutrient level in soils supporting oil palm. Fields 53 and 56 is adequate in $\mathrm{Fe}$ and $\mathrm{Zn}$ but not adequate in $\mathrm{Mn}$ and $\mathrm{Cu}$ while field 71 was adequate in $\mathrm{Zn}, \mathrm{Fe}$, and $\mathrm{Cu}$ but not in $\mathrm{Mn}$. Adequate fertilizers of these micronutrient as their respective sulphates or impurities should be added to maintain proper micronutrient level. 
BAJOPAS Volume 14 Number 1,June, 2021

\section{Correlation analysis}

In the field 53, $\mathrm{pH}$ had a positive and significant correlation with Fe and $\mathrm{Zn}(r=0.9995, \mathrm{p} \leq 0.05)$ and $(r=0.9934, p \leq 0.05)$ respectively. This means that increase in $\mathrm{pH}$ lead to increase in $\mathrm{Fe}$ and $\mathrm{Zn}$. This could be as a result of the type of fertilizer used in the field. Silt had a negative and significant correlation with Fe and Zn ( $r=-0.9937, p \leq 0.05)$ and $(r=-$ $0.9995, p \leq 0.05$ ). Clay had a negative and significant correlation with $\mathrm{Cu}(\mathrm{r}=-0.9969, \mathrm{p} \leq 0.05)$.

While in field $56, \mathrm{pH}$ had a negative and significant correlation with $\mathrm{Mn}$ and $\mathrm{Cu}(\mathrm{r}=-0.7559, \mathrm{p} \leq 0.05)$ and $(r=-0.9975, p \leq 0.05)$ respectively. This implies that a decrease in $\mathrm{pH}$ leads to increase in $\mathrm{Cu}$ and $\mathrm{Mn}$ in this field. The correlation between clay and Fe was positive and highly significant $(r=1, p \leq 0.05)$. Clay also had a positive and significant correlation with $\mathrm{Cu}$ $(r=0.9929, p \leq 0.05)$ implying that increase in the clay content of the field leads to the increase in the $\mathrm{Cu}$ and Fe content.

The field 71, $\mathrm{pH}$ had a positive and significant relation with $\mathrm{Fe}$ and $\mathrm{Zn}(r=0.9997, \mathrm{p} \leq 0.05)$ and $(r=$ $0.9997, p \leq 0.05$ ) respectively. This means Fe and $\mathrm{Zn}$ increases as $\mathrm{pH}$ increases as observed in field 31 as well. This could mean low phosphorus level (phosphorus have an antagonistic relationship with $\mathrm{Fe}$ and $\mathrm{Zn}$ ), and possibly the fertilizer used could contain $\mathrm{Fe}$ and $\mathrm{Zn}$ impurities. Silt had a negative and significant correlation with $\mathrm{Cu}(\mathrm{r}=-0.9902, \mathrm{p} \leq$ $0.05)$. Clay however had a positive and significant correlation with $\mathrm{Cu}(r=0.9988, \mathrm{p} \leq 0.05)$.

Table 3: Correlation coefficient $(\mathrm{r})$ between $\mathrm{pH}$, soil particles and the selected micronutrients of the sampled fields

$\begin{array}{llll}\mathrm{Mn} & \mathrm{Fe} & \mathrm{Cn}\end{array}$

\section{Field 53}

$\mathrm{pH}$

Sand

Silt

Clay

$\begin{array}{ll}-0.7559 * & -0.982 \\ -0.9707 & -0.9608 \\ -0.5 & -0.866 \\ -0.7559 & 1 * *\end{array}$

$\begin{array}{ll}-0.9975 * & 0.9286 \\ -0.9209 & -0.9959 \\ -0.9194 & -0.7559 \\ 0.9929 * 0.982 & \end{array}$

Field 56

$\begin{array}{lllll}\text { pH } & -0.866 & 0.9997 * & 0.9814 & 0.9997 * \\ \text { Sand } & 0.7559 & -0.9866 & -0.9274 & -0.9864 \\ \text { Silt } & 0.982 & -0.936 & -0.9902 *- & 0.9364 \\ \text { Clay } & -0.9286 & 0.9857 & 0.9988^{*} & 0.9858\end{array}$

Field 71

\begin{tabular}{lllll} 
pH & 0.803 & $0.9995^{*}$ & -0.946 & $0.9934^{*}$ \\
Sand & -0.9177 & 0.9995 & 0.1923 & -0.596 \\
Silt & -0.8808 & $0.9995^{*}$ & 0.8891 & $-0.9995^{*}$ \\
Clay & 0.5 & 0.9995 & $-0.9969 *$ & 0.866 \\
\hline
\end{tabular}

*correlation is significant at $0.05 \%$

** correlation is significant at $0.01 \%$

\section{CONCLUSION}

This study revealed that there was generally low and inadequate micronutrient to sustain the full potential of the oil palm as revealed by their estimated availability in the field. It also revealed that different management practices influence the level of micronutrients in the soil as there were great differences in the soil $\mathrm{Fe}, \mathrm{Mn}, \mathrm{Zn}$, and Cu across the fields. The concentration of the micronutrients (Fe, $\mathrm{Mn}, \mathrm{Zn} \mathrm{Cu}$ ), in field 53were not extreme (neither the

\section{REFERENCES}

Aghimien, A.E. (1985). Micronutrients Status of Hydromorphic soils from southern Nigeria. Nigerian Journal of palms and oil seeds (1988) Vol. 9, 16-36

Alloway BJ (2008) Micronutrients and crop production: An introduction. In 'Micronutrient deficiencies in global crop production'. (Ed BJ Alloway) pp. 1-39. (Springer Publishing) highest nor lowest) when comparing the three fields indicating that (Best Management Practice) may be the most desirable for maintaining good micronutrient level in soils supporting oil palm. Field 53 and field 56 is adequate in $\mathrm{Fe}$ and $\mathrm{Zn}$ but not adequate in $\mathrm{Mn}$ and $\mathrm{Cu}$ while field 71 was adequate for $\mathrm{Zn}, \mathrm{Fe}$, and $\mathrm{Cu}$ but not in $\mathrm{Mn}$. Adequate fertilizers of these micronutrients as their respective sulphates or impurities should be added to maintain proper micronutrient level.

AtefehRamezanian, Colin D. Campbell, Sigrun Dahlin, Stephen Hillier and Ingrid Öborn (2010) Relation of soil mineralogy and microbial communities based on micronutrient status 19th World Congress of Soil Science, Soil Solutions for a Changing World $271-6$,

Bouyoucos, G.H (1951). A recalibration of the hydrometer method for making mechanical analysis of soil. Agronomy Journal 43: 434 438 
BAJOPAS Volume 14 Number 1,June, 2021

Brady, N. C. and Weil, R. R. (1996). The nature and properties of soil (11th Edition). New Jersey: Prentice-Hall, Inc. Page 740.

Daiswal, P.C. (2004): Soil, plant and water analysis kalgani publishers, Ludhiani, New Delhi Noida (U.P) pp264

Gee, G.W and Or, D. (2002) Particle size analysis. Pp 255 - 293. In. J. H. Dane and G.C Topp (eds). Methods of Soil Analysis, part 4, physical methods. Soil Science Society, American. Book series No 5 Madison, Wisconsin USA

Nigerian Institute for Oil Palm Research (NIFOR) (1999). A manual on oil palm production. PP 45.

Ogunkunle, A.O (1993): Soil in land suitability evaluation: an example with oil palm I Nigeria. Soil use and management. 9: 37 42

Okolo C.C., Okolo E.C., Nnadi A.L., Obikwelu F.E., Obalum S.E. and Igwe C.A. The Oil Palm (Elaeisguineensis Jacq): Nature's Ecological Endowment to Eastern Nigeria, Journal of Tropical Agriculture, Food, Environment and Extension, Volume 18 Number 3 (September 2019) pp. 48-57

Opeke L.K. (1987). Tropical tree crops. Published by Woye and sons (Nig) limited, Pp: 252-266

Sundaram A.; Sundaram K. M. S. Solubility products of six metal-glyphosate complexes in water and forestry soils, and their influence on glyphosate toxicity to plants.J. Environ. Sci. Health Part B 1997, 32, 583-598

Udom D.S. (2002). Declining yield of Oil Palm: A case study of our Oil Palm plantation In Nigeria and Cameroon. Niger Agric J. 33:32-27
Maclean K.S. and Langille. W.. (1976). The extractible trace element content of coarse textured Annapolis valley soils and the influence of $\mathrm{pH}$, organic matter and clay content. Communication in soil and plant analysis 7: $777-785$

McKenzie RH. 2001. Micronutrient requirements of crops. Alberta Agriculture and Rural development

http://www1.agric.gov.ab.ca/\$department/ deptdocs.nsf/all/agdex713.Acessed on 21 July 2011. 